\title{
Barnets inste grind
}

\author{
- Det største er å oppleve at man har klart å komme frem til barnets innerste grind, og at det \\ da slipper deg inn, sier barne- og ungdomspsykiater Trond H. Diseth ved Barneklinikken ved \\ Rikshospitalet. Han arbeider med barn med alvorlige, kroniske, stigmatiserende og av og til \\ dødelige somatiske sykdommer.
}

Diseths unike evne til å samarbeide, alltid med barnas beste for øye, er noe kollegene fremhever. På Rikshospitalet har han gått inn i det somatiske miljøet og gjort seg og faget han representerer uunnværlig. Han har bidratt til oppmerksomhet rundt psykiske konsekvenser av sykehusbehandling og har påvirket behandlingsforløpet av flere tilstander. Særlig har han engasjert seg i tabubelagte sykdommer. Her har han gjort viktig nybrottsarbeid.

\section{Hodestups betatt}

- Hvorfor ble du lege?

- På ungdomsskolen var jeg utplassert $\mathrm{i}$ barnehage og fikk sansen for å jobbe med nettopp barn. På denne tiden mistet jeg også en bror på grunn av en blodsykdom. Foreldrene mine ble frarådet å involvere oss søsken. Det skulle ikke snakkes om sykdommen. De var uenige i vurderingen og smuglet oss nærmest inn bakveien på sykehuset. Jeg ble opptatt av hvordan man kunne hjelpe barn til å få en trygg plattform og bestemte meg for å bli barnelege.

Under studiet var det gode forelesninger i pediatri, men så ble jeg endelig introdusert for barne- og ungdomspsykiatrien. I kullboken fortelles det at jeg i løpet av én forelesning flyttet meg fra bakerste til første rekke $\mathrm{i}$ forelesningssalen og ble hodestups betatt. Jeg gikk frem, sa jeg hadde funnet faget mitt, og spurte hva jeg nå skulle gjøre. Jeg fikk råd om først å lære mer om friske barns utvikling.

Etter turnus ble jeg kommunelege i Larvik og hadde ansvar for helsestasjonene og skolehelsetjenesten. Som en del av spesialiseringen kom jeg til Rikshospitalet i 1990. På det tidspunktet var det den eneste barne- og ungdomspsykiatriske enhet i landet som var organisert under en pediatrisk avdeling. Da var jeg endelig kommet hjem. Siden har jeg vært her og har aldri angret en dag.

\section{Barnet i sentrum}

- Hvordan er det å jobbe med barn?

- Det er utfordrende og samtidig svært givende. Man må ha med seg både det biologiske, det utviklingspsykologiske, det familiære og det kulturelle perspektivet inn i møtet med det enkelte barn. Deres måte å tenke om seg selv og deres plass i verden på og hvordan de forholder seg til sykdom forandrer seg fra år til år. Min fanesak er den biopsykososiale tilnærmingen, og jeg kan ikke tenke meg et bedre fagområde for denne modellen enn nettopp arbeid med barn. Den første utfordringen er alltid allikevel å etablere en trygg kontakt med barnet. - Hvordan gjør du det?

- Du må kanskje allerede på venteværelset legge deg ned på alle fire og sende en bil under sofaen der barnet har gjemt seg. Kanskje kommer bilen tilbake. Det er mange kanaler inn til barn.

Kontoret hans er fullt av leker, bøker og spill. - Jeg ser hvert barn som et nytt «land-

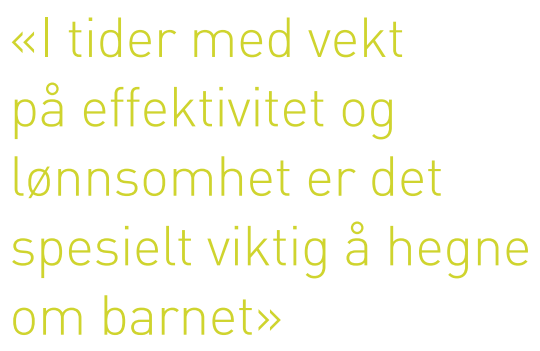

skap» som jeg med ydmykhet, respekt, tillit og varhet er invitert inn i. Det handler om først å finne frem til porten, og da hender det at barnet slipper deg inn. Når du først har sluppet innenfor, er det utrolig å oppleve den enorme tilliten og åpenheten du kan bli vist fra et barn. Jeg merker jeg blir berørt bare av å snakke om det.

- Synes du barnets perspektiv blir ivaretatt på sykehus i dag?

- Denne seksjonens store flaggsak har vært å ivareta barne- og familieperspektivet $i$ et somatisk sykehus. I tider med vekt på effektivitet og lønnsomhet er det spesielt viktig å hegne om barnet. Jeg opplever at man i helsevesenet $i$ dag har et mer bevisst forhold til og ønske om å ta vare på barn på sykehus. Veien dit har vært lang, og jeg gir mine forgjengere stor anerkjennelse for deres styrke og utholdenhet. Alle som jobber med barn, blir imidlertid veldig dedi- kert, og et brennende engasjement er viktig for å klare å stå i alt det alvorlige som skjer på sykehus. Jeg er også svært stolt av å kunne lede en seksjon der mine medarbeidere, til tross for alle utfordringene, hver dag gleder seg til å gå på jobb.

- Dere har gode rammer?

- Det har ikke vært en selvfølge. Vi representerer et «mykt» fag og kan lett overkjøres. I tider hvor man tenker produktivitet og drift, kan vårt perspektiv være en utfordring. Det har vært viktig å synliggjøre behovet for denne funksjonen. Det er gjort mye forskning som viser at hvis man ivaretar den mentale helse på sykehuset, resulterer det ikke bare i økt pasienttilfredshet, men også i bedre behandling, økt etterlevelse og faktisk kortere sykdomsforløp. Denne seksjonen ble etablert i 1979 og startet med åtte fagpersoner, nå er vi 25. Jeg er stolt over at vi gjennom vårt kliniske arbeid og vår forskning har vist at vi har en plass innenfor somatikken.

\section{Tabu og stigma}

- Du har forsket mye på tabubelagte og stigmatiserende tilstander. Hvorfor ble du opptatt av dette?

- À gi kronisk somatisk syke barn et rom for å snakke om sine tabubelagte symptomer erfarte jeg tidlig var viktig, og jeg ønsket mer systematisk kunnskap om det. I 1992 startet jeg et doktorgradsprosjekt om medfødte misdannelser i ano-, rekto- og urogenitalområdet.

- Hva er det viktigste som kom ut av forskningen?

- For det første var det betydningsfullt å sette på dagsordenen at somatiske symptomer, for eksempel inkontinens, kan ha store mentale og psykososiale konsekvenser. Dessuten ga det et viktig budskap til barne- og ungdomspsykiatrien om at disse barna faktisk er vårt ansvar. Aller mest stolt er jeg kanskje over å ha drevet frem prosjekter som viste at våre medisinske behandlingsprotokoller hadde alvorlige psykiske følger for barn og foreldre. Disse ble da endret som følge av ny kunnskap.

- Hva gikk dette ut på?

- Dette handler blant annet om analatresi, medfødt lukket endetarm. Barna ble 


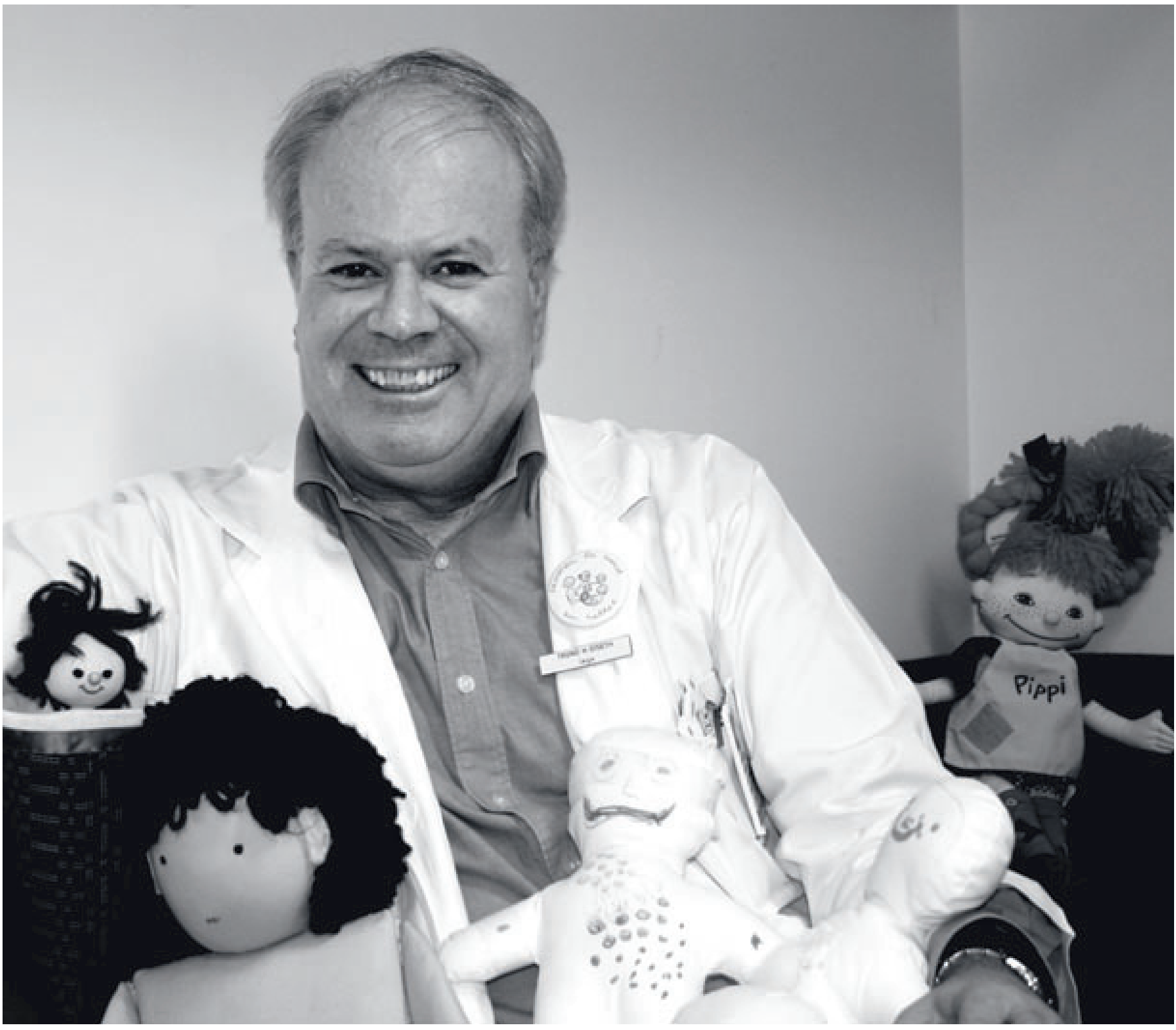

Foto Marit Tveito

\section{Trond Haaken Diseth}

Født 5. juli 1957

- Cand.med. Universitetet i Oslo 1984

- Dr.med. Universitetet i Oslo 1997

- Spesialist i barne- og ungdomspsykiatri 2000

- Professor ved Det medisinske fakultet ved Universitetet i Oslo fra 2005

- Avdelingsoverlege ved Seksjon for psykosomatikk og CL-barnepsykiatri, Oslo universitetssykehus, Rikshospitalet, fra 2004 operert, og for å holde anus åpen fikk foreldrene beskjed om å analdilatere barnet en til to ganger daglig gjennom flere år. Det er lett å forstå at dette kunne være vanskelig og utfordrende for samspillet. Forskningen viste at varigheten av blokkingen var den viktigste prediktor for de mentale helseproblemene disse barna viste da de ble eldre.

Dette førte til at vi som et av de første land i verden la om vår prosedyre.

- Hva ble annerledes?

- For det første viste det seg at ikke alle trengte å gjennomføre blokking. Nå er det bare et lite mindretall som må ha slik behandling. Varigheten er blitt kraftig redusert, fra flere år til få måneder. Hvis det blir utfordrende, er det helsepersonell som utfører behandlingen. Terskelen for å bruke anestesi er også lavere. Jeg er opptatt av at forskning skal ha et klinisk utgangspunkt og at resultatene skal kunne tilbakeføres til klinikken. Det er tilfredsstillende å se at man kan påvirke somatiske behandlingsprotokoller. At det barnekirurgiske fagmiljøet tar resultatene innover seg, kommer jo også av at man har gjensidig respekt og et tillitsfullt samarbeid. Jeg ser dette som et resultat av vår integrerte tverrfaglige organisering, hvor et trygt, lojalt og nært samarbeid har vokst frem over mange år.

- Du har også arbeidet med forstyrrelser i kjønnsutviklingen, tidligere kalt intersex.

- Ja, noen barn er født med en alvorlig genital anomali som gjør at kjønnet ikke kan fastsettes med sikkerhet rett etter fødselen. 
- Hva gjør man da?

- I «gamle dager», det vil si frem til 1997, mente man at barn er født kjønnsnøytrale. Fagmiljøet trodde da at man ved en genital anomali hadde et vindu på to års tid hvor man kunne velge kjønn, operere og så oppdra barnet deretter. Det viste seg at alle disse barna ble operert til å være jenter, som er det kirurgisk enkleste. Mange ble henvist til meg da de kom i en alder hvor de psykologiske komplikasjonene utviklet seg. Barnet, som var operert til jente, kunne selv oppfatte seg som gutt, og foreldrene observerte svært «gutteaktig» atferd. Jeg erkjente at verken sosial påvirkning, oppdragelse, kirurgi eller psykoterapi kunne få disse barna til å tenke annerledes. Vi måtte som fagfolk ta innover oss at kjønnsidentiteten ikke avgjøres av ytre genitalia, men av hjernen og hva den er påvirket av når det gjelder hormoner og gener i fosterlivet. - Så når det gjelder født slik eller blitt slik...?

- Det er nå gode holdepunkter for å si at man er «født slik». Hvilket «hormonbad» hjernen var påvirket av mellom 5. og 12 . fosteruke er viktig for kjønnsrolleatferden, mens samspillet mellom spesifikke gener og hormoner er viktig for kjønnsidentiteten. - Det handler ikke bare om X- og Y-kromosomer?

- Nei, det kreves et omfattende tverrfaglig samarbeid med sofistikert og tidkrevende utredning for å komme frem til hvilket kjønn barnet er født som. Vi mener at det er bedre å leve som gutt i en guttekropp enn å leve i feil kropp, selv om man ikke oppnår et optimalt kirurgisk resultat. Da vi kunne vise dette i forskningsdata, la vi også her som et av første land i verden om protokollen for kjønnsbestemmelse hos disse barna.

\section{Kryss i taket}

I Diseths hvite kontortak ser man en rekke daterte kryss med rød sprittusj.

- Av og til virker en setning eller en hen- delse så gjennomgripende viktig at jeg sier «kryss i taket», og da gjør jeg også nettopp det. I vår seksjon er det kultur for å være kreativ, eklektisk og ta det beste fra ulike teorier. Her er det vokst frem mye originalt arbeid og tatt i bruk selvlagede historier, eventyr, tegninger, musikk, PC-spill og hypnose. At man kan bruke intervensjoner som ikke hører inn under en bestemt kategori, er stimulerende. Kryssene i taket har jeg aldri lest om eller gått på kurs for, men de dukket opp og er svært virksomme.

- Alt som «virker» er greit?

- Vi tar i bruk alt det som virker støttende og mestrende for barna. På den måten ønsker vi å forebygge uheldige psykososiale virkninger av en sykdom og hjelpe

\section{«Vi tar i bruk alt det som virker støttende og mestrende for barna»}

hele familien til å mestre situasjonen. Det kan også dreie seg om noe så eksistensielt som å mestre det å skulle dø.

- Tidligere skulle man ikke snakke med barn om døden. Hva gjør det med et barn og en familie?

- Barn er utrolig ivaretakende, hensynsfulle og nesten selvutslettende overfor sine foreldre. De kan spille glade for å ta vare på familien, men lider i stillhet. Undersøkelser viser at foreldre i etterkant angrer hvis de ikke ga barnet anledning til å snakke om døden. Åpen kommunikasjon og å ha barnet med som samarbeidspartner og medspiller gjennom behandlingen er viktig. Det er en utfordrende balanse å ta vare på håpet og samtidig åpne opp for å snakke om døden når barnet er rede for det.

- Opplever du ofte at barna skjønner at de skal dø?
- Ja, alltid - og da må man være tilgjengelig. Jeg merker gjerne at barnet vil gjøre noe annet enn det vi har gjort før, spør kanskje om jeg har kjent barn som har dødd, hva vedkommende tenkte på og hva vi snakket om. Det er en sterk, men utrolig givende opplevelse å få lov til å hjelpe barn med å forberede seg på døden og å «ro dem over».

\section{Påfyllet}

- Hva håper du å oppnå?

- Jeg håper at jeg en dag skal få slippe hele tiden å måtte slåss for det helhetlige tankegodset og at den biopsykososiale sykdomsforståelsen endelig er blitt godt integrert på alle nivåer.

- Hva gjør deg fornøyd - utenom jobben?

- Utenom jobben? Jo, jeg har et liv utenom jobben. Jeg er blitt bevisst på å lage meg mine egne rom. Det er også en av grunnene til at jeg ikke lenger har mobiltelefon. Jeg måtte ta tilbake tiden. Man kan og skal ikke alltid være tilgjengelig. I mine rom setter jeg stor pris på god musikk, litteratur og mine to paradis på jorden - Nordmarka og Ula. I disse landskapene henter jeg meg virkelig inn. Jeg er glad i å gå utenfor de store løypene. Jeg samler på gamle Nordmarks-kart og går opp gamle stier. På hytta i Ula har jeg tilbrakt mye av livet. Når jeg nærmer meg dette paradiset, kan jeg fysisk kjenne at skuldrene senker seg.

Han tenker seg om, puster dypt og skal til å fortsette. Men intervjuet må en gang ta slutt. Jeg har stoff til mange artikler. På vei ut av kontoret ser jeg to sitater ved døren som Diseth nok lever etter: «Låt mig verka medan dagen brinner» (C. Mille) og «... att brinna i det levandes ögonblick» (K. Boye).

\section{Marit Tveito}

marit.tveito@me.com

Vinderen DPS 